\title{
Komplikasi Mual Muntah Pascaoperasi Bedah Saraf
}

\author{
Dimas Rahmatisa*), Marsudi Rasman**), Siti Chasnak Saleh"*) \\ ${ }^{*}$ Departemen Anestesiologi dan Terapi Intensif Rumah Sakit Pusat Otak Nasional Jakarta, \\ ${ }^{* *}$ Departemen Anestesiologi dan Terapi Intensif Fakultas Kedokteran Universitas Padjadjaran-RSUP Dr. Hasan \\ Sadikin, ${ }^{* * *}$ Departemen Anestesiologi dan Reanimasi Fakultas Kedokteran Unversitas Airlangga-RSUD. Dr. \\ Soetomo Surabaya
}

\begin{abstract}
Abstrak
Mual, dan muntah adalah termasuk diantara keluhan-keluhan paling sering terjadi, dan dapat timbul pada kasus anestesia umum, regional, atau lokal. Insiden muntah sekitar 30\%, kejadian mual adalah sekitar 50\%, dan sebagian dari pasien berisiko tinggi, angka postoperative nausea and vomitting (PONV) bisa mencapai 80\%. Faktor risiko PONV paling besar adalah jenis kelamin wanita, diikuti oleh riwayat motion sickness dan usia, lalu penggunaan anestesia inhalasi, durasi anestesia, penggunaan opioid pasca operasi dan terakhir penggunaan $\mathrm{N}_{2} \mathrm{O}$. Pada kasus operasi bedah saraf, khusunya pada pengangkatan tumor, terdapat beberapa bahaya yang dapat terjadi bila PONV ini tidak ditangani dengan baik. Pada pasien bedah saraf, secara umum, kita harus menjaga agar tekanan intra kranial tetap dalam batas normal, sehingga aliran darah otak, dan tekanan perfusi otak dapat terjaga dengan baik. Jika terjadi PONV, maka tekanan intraabdomen akan meningkat, dan tentunya akan juga berpengaruh kepada kenaikan tekanan intrakranial. Disamping itu, pasien pasca pengangkatan tumor, akan rentan terhadap terjadinya perdarahan ulang yang tadinya sudah berhenti saat selesai operasi. Perdarahan dapat terjadi pada tumor bed dan dapat menyebabkan komplikasi yang fatal. Dari berbagai penelitian mengenai PONV pada operasi bedah saraf, faktor lokasi operasi tidak terlalu banyak berpengaruh. Operasi infratentorial memiliki angka PONV yang lebih tinggi, dihubungkan dengan lebih lamanya durasi operasi.
\end{abstract}

Kata kunci: PONV, nausea, vomiting, mual, muntah, neurosurgery, tumor, otak

JNI 2019; 8 (1): 72-82

\section{Postoperative Nausea and Vomiting (PONV) Complication after Neurosurgery}

\begin{abstract}
Nausea, and vomiting are among the most common complaints, and may occur in the case of general, regional, or local anesthesia. The incidence of vomiting is about $30 \%$, the incidence of nausea is about $50 \%$, and some of the patients are at high risk, Postoperative nausea and vomitting (PONV) rate can reach $80 \%$. The strongest predictor of PONV is female gender, followed by history of motion sickness, age, inhalation anesthetic drugs, postoperative opioid, and using of nitrous oxide. In neurosurgery patients, in general, we must keep the intra-cranial pressure within normal limits, so that the cerebral blood flow, and the cereberal perfussion pressure can be well preserved. If there is PONV, the intraabdominal pressure will increase, and will certainly also affect the intracranial pressure. In addition, patients post-tumor removal, will be vulnerable to the occurrence of re-bleeding that had been stopped when completed surgery. Bleeding can occur in tumor beds and can cause fatal complications. According to various studies on PONV in neurosurgical surgery, the location factor of the surgery did not have much effect. Infratentorial surgery has a higher PONV number, associated with longer duration of operation.
\end{abstract}

Key words: PONV, nausea, vomiting, neurosurgery, brain, tumor

JNI 2019; 8 (1): 72-82 


\section{Pendahuluan}

Postoperative Nausea and Vomiting (PONV) adalah kondisi yang umum terjadi dan seringkali menyusahkan pasien. Insiden muntah sekitar $30 \%$ sedangkan insidens dari mual adalah sekitar $50 \%$, dan bahkan pada populasi dengan risiko tinggi, angka PONV bisa mencapai $70 \%$ hingga $80 \% .^{1,2}$ Masalah PONV yang belum terselesaikan dapat terjadi di postanesthesia care unit (PACU) ataupun di ruang rawat, dan dapat menyebabkan tertundanya pasien pulang, sehingga akhirnya dapat meningkatkan biaya yang dikeluarkan. ${ }^{3,4}$

Mual didefinisikan sebagai keadaan subyektif, yang tidak menyenangkan disertai keinginan untuk muntah. Biasanya dirasakan di bagian belakang kerongkongan dan epigastrium, yang disertai hilangnya tonus gastrik, dan juga kontraksi dari duodenum, dan refluks isi usus ke lambung. Retching adalah kontraksi ritmik, spasmodik dari otot-otot pernapasan, termasuk diafragma, dinding dada, dan otot perut tanpa disertai keluarnya isi lambung. Muntah adalah keluarnya isi lambung melalui mulut dan bersamaan timbul kontraksi otot-otot perut, turunnya diafragma, dan terbukanya bagian kardia dari lambung. ${ }^{5,6}$

Meskipun saat ini sudah terjadi perkembangan di bidang obat-obatan maupun teknik anestesia, PONV masih tetap menjadi keluhan yang banyak terjadi setelah operasi. Selain perasaan tidak nyaman, risiko terjadinya gangguan keseimbangan elektrolit, dehidrasi, yang akan menimbulkan efek buruk terhadap luka operasi, dan memperpanjang masa rawat.?

Mual atau muntah yang terus menerus akan menyebabkan dehidrasi, imbalans elektrolit, dan tertundanya keluar dari rumah sakit. Mual, muntah, atau regangan perut, dapat menyebabkan meningkatnya tekanan vena, tekanan tinggi pada jahitan luka operasi, flap yang menjadi berdarah, juga bila pasien masih dalam pengaruh sedasi atau anestesia, dapat menyebabkan terjadinya aspirasi. ${ }^{6}$ Pada kasus operasi bedah saraf, khususnya pada pengangkatan tumor, terdapat beberapa bahaya yang dapat terjadi bila PONV ini tidak ditangani dengan baik. Pada pasien bedah saraf, secara umum, kita harus menjaga agar tekanan intra kranial tetap dalam batas normal, sehingga aliran darah otak, dan tekanan perfusi otak dapat terjaga dengan baik. Jika terjadi PONV, maka tekanan intraabdomen akan meningkat, dan tentunya akan juga berpengaruh kepada kenaikan tekanan intrakranial. Disamping itu, pasien pasca pengangkatan tumor, akan rentan terhadap terjadinya perdarahan ulang yang tadinya sudah berhenti saat selesai operasi. Perdarahan dapat terjadi pada tumor bed dan dapat menyebabkan komplikasi yang fatal. ${ }^{6}$

Mekanisme terjadinya mual dan muntah berasal dari cara yang berbeda. Mual diakibatkan oleh adanya rangsangan pada forebrain sedangkan mual berasal dari rangsangan pada hindbrain. Berbagai rangsangan yang berbeda dapat merangsang pada pusat muntah yang terletak pada medulla oblongata. Pusat muntah ini menerima berbagai macam sinyal dari saraf aferen pada traktus gastrointestinal, chemoreceptor trigger zone (CTZ), korteks sereberi, serebelum, dan sistem vestibuler. Secara khusus, CTZ terletak pada ventrikel 4 dari batang otak, dan berada di luar sawar darah otak, oleh karena itu dapat bersentuhan dengan berbagai jenis obat-obatan, misalnya obat-obat anestesia inhalasi dan opioid. Dopamin, opioid, histamin, asetilkolin, resepetor 5-hidroksitriptamin 3 (5-HT3), dan reseptor neurokinin-1 (NK-1), dihubungkan dengan menstimulasi pusat muntah, hal ini menunjukkan bahwa bukan hanya satu golongan obat, namun berbagai golongan obat diperlukan untuk dapat mencegah PONV. ${ }^{8}$

\section{Faktor Risiko PONV}

Apfel menyatakan ada empat faktor risiko yang berkaitan dengan PONV, yaitu jenis kelamin wanita, riwayat PONV sebelumnya, menggunakan opioid untuk analgetik pasca operasi, dan bukan perokok. ${ }^{9}$ Sebagai tambahan, Koivuranta melaporkan 5 faktor risiko yang berhubungan dengan PONV, yaitu durasi operasi lebih dari 1 jam, jenis kelamin wanita, riwayat PONV sebelumnya, riwayat motion sickness, dan bukan perokok. Dari penelitian yang dilakukan Apfel, didapatkan bahwa faktor risiko PONV yang paling kuat adalah jenis kelamin wanita, diikuti oleh riwayat motion sickness dan usia, lalu 


\begin{tabular}{|l|c|}
\hline \multicolumn{1}{|c|}{ Risk Factors } & Points \\
\hline Female Gender & 1 \\
\hline Non-Smoker & 1 \\
\hline History of PON & 1 \\
Postoperative Opioids & 1 \\
\multicolumn{1}{|c|}{ Sum = } & $0 \ldots 4$ \\
\hline
\end{tabular}

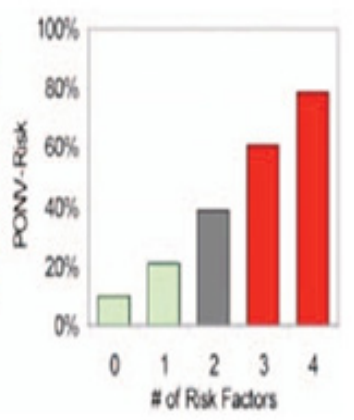

Gambar 1. Faktor Risiko PONV ${ }^{1}$

penggunaan anestesia inhalasi, durasi anestesia, penggunaan opioid pasca operasi dan terakhir penggunaan $\mathrm{N}_{2} \mathrm{O}$. Jenis pembedahan, puasa sebelum pembedahan, dan siklus menstruasi dikatakan tidak berhubungan dengan PONV. ${ }^{8}$

Dari penelitian, diduga adanya kemungkinan pengaruh genetika pada terjainya PONV. Terdapat gen OPRM1 yang belakangan ini sering diteliti. Pada penelitian ditemukan bahwa risiko PONV tinggi pada individu yang memiliki gen A118, yang merupakan varian dari OPRM $1 .{ }^{8}$ Individu yang memiliki gen A118 memiliki derajat nyeri yang paling rendah, namun memiliki insidens mual yang lebih tinggi. Penelitian mengenai genetika yang paling sering dilakukan adalah mengenai 5-HT3 reseptor (subunit A dan B), reseptor muskarinik tipe 3, reseptor $\mathrm{D} 2$, repetor katekol-o-metiltransferase, alfa 2 adrenoreseptor, adenosin trifosfat, sitokrom P450, dan UDPglukoroniltransferase. ${ }^{8-11}$

\section{Terapi Farmakologik}

Seperti disebutkan di atas, penggunaan dua atau lebih obat yang memiliki kelas yang berbeda, dirasakan cukup efektif karena mekanisme yang kompleks mendasari patogenesis PONV. Secara khusus, kombinasi terapi sangat penting untuk pasien berisiko tinggi. Jika PONV terjadi, meskipun sudah diberikan antiemetik, maka antiemetik penyelamatan harus dipilih dari obat-obatan dari golongan yang berbeda dari sebelumnya. Karena itu penting untuk memiliki pengetahuan mengenai kelas masing-masing obat dan mekanisme kerjanya. ${ }^{8}$

\begin{tabular}{|l|c|}
\hline Risk Factors & Points \\
\hline $\begin{array}{l}\text { Surgery } \geq 30 \\
\text { min. }\end{array}$ & 1 \\
\hline $\begin{array}{l}\text { Age } \geq 3 \\
\text { years }\end{array}$ & 1 \\
$\begin{array}{l}\text { Strabismus } \\
\text { surgery }\end{array}$ & 1 \\
$\begin{array}{l}\text { History of } \\
\text { POV or } \\
\text { PONV in } \\
\text { relatives }\end{array}$ & 1 \\
\hline \multicolumn{1}{|c|}{ Sum = } & $9 \ldots .4$ \\
\hline
\end{tabular}

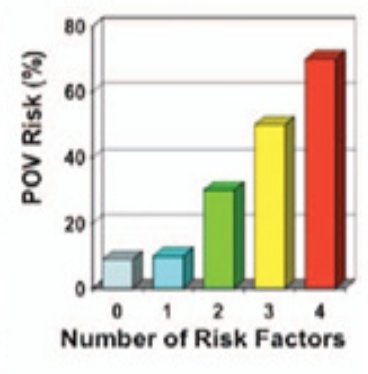

Gambar 2. Faktor Risiko PONV pada Anak ${ }^{1}$

\section{Antagonis Reseptor Kolinergik}

Antagonis reseptor kolinergik, termasuk golongan antiemetik yang paling tua. Golongan obat ini bekerja dengan cara menghambat reseptor muskarinik pada sereberal korteks dan pons. Pada golongan ini, obat yang paling efektif adalah skopolamin, yang merupakan inhibitor kompetitif pada reseptor ganglion muskarinik pada sistem saraf parasimpatis, dan bekerja langsung pada sistem saraf pusat, dengan menghambat transmisi kolinergik pada nukleus vestibular. Obat ini diberikan transdermal, karena waktu paruhnya yang singkat. Bisa diberikan pada malam hari sebelum pembedahan, atau bisa juga diberikan 2-4 jam sebelum pembedahan. Pada penelitian meta-analisis, skopolamin transdermal profilaksis, efektif untuk menurunkan PONV. Efek samping dari skopolomin adalah mulut kering yang biasanya terjadi pada 24 jam pertama, dan gangguan penglihatan yang biasa terjadi pada 24-28 jam setelah pembedahan. ${ }^{1,8,10}$

\section{Antagonis Reseptor Histamin}

Antagonis reseptor histamin, telah terbukti untuk menghambat PONV. Obat ini bekerja dengan cara menghambat resptor asetilkolin yang berada pada system vestibular, dan pada nukleus traktur solitarius. Obat golongan ini tidak spesifik dibandingkan dengan obat golongan lainnya. Penelitian obat golongan ini masih terbatas. Dibandingkan dengan golongan antagonis serotonin golongan ini memiliki potensi sama atau sedikit lebih lemah. ${ }^{1}$ Efek samping dari obat ini adalah mulut kering, mengantuk, retensi urin, dan gangguan penglihatan. Contoh obat dari golongan ini adalah dimenhidrat dan meklizin..$^{8,10}$ 
Tabel 1. Rekomendasi Jenis, Dosis, dan Waktu Pemberian dari Berbagai Antiemetik ${ }^{1}$

\begin{tabular}{lll}
\hline Obat & Dosis & Waktu pemberian \\
\hline Arprepitant & $40 \mathrm{mg}$ & Saat induksi \\
Casopitant & $150 \mathrm{mg}$ & Saat induksi \\
Deksametason & $4-5 \mathrm{mg} \mathrm{IV}$ & Saat induksi \\
Dimenhidrat & $1 \mathrm{mg} / \mathrm{kg} \mathrm{IV}$ & \\
Dolasetron & $12.5 \mathrm{mg}$ IV & Akhir pembedahan \\
Droperidol & $0.0625-1.25 \mathrm{mg} \mathrm{IV}$ & Akhir pembedahan \\
Efedrin & $0.5 \mathrm{mg} / \mathrm{kg} \mathrm{IM}$ & \\
Granisetron & $0.35-3 \mathrm{mg}$ IV & Akhir pembedahan \\
Haloperidol & $0.5-<2 \mathrm{mg} \mathrm{IM} / \mathrm{IV}$ & \\
Metilprednisolon & $40 \mathrm{mg}$ IV & \\
Ondansetron & $4 \mathrm{mg}$ IV, $8 \mathrm{mg}$ & Akhir pembedahan \\
Akhir pembedahan & $0.075 \mathrm{mg} \mathrm{IV}$ & Saat induksi \\
Perfenazin & $5 \mathrm{mg}$ IV & \\
Prometazin & $6.25-12.5 \mathrm{mg}$ IV & \\
Ramosetron & $0.3 \mathrm{mg} \mathrm{IV}$ & Akhir pembedahan \\
Rolapitant & $70-200 \mathrm{mg}$ & Malam sebelumnya atau 2 \\
Skopolamin & Transdermal patch & Akhir pembedahan \\
Tropisetron & $2 \mathrm{mg} \mathrm{IV}$ & \\
\hline
\end{tabular}

\section{Serotonin Antagonis}

Antagonis 5-HT3 adalah antiemetik yang paling umum digunakan dalam manajemen perioperatif. Obat-obat ini bekerja di perifer dengan cara memblokir aferen vagal usus dan juga bekerja sentral di area postrema. ${ }^{12}$ Ondansetron Antagonis 5-HT3 yang paling sering digunakan di orang barat adalah ondansetron, dan obat golongan ini juga yang paling sering diteliti dari golongan serotonin antagonis. Banyak studi skala besar dan ulasan sistematis Cochrane telah menunjukkan bahwa pemberian ondansetron profilaksis dapat menurunkan PONV sebesar 25\%. ${ }^{9,10}$ Investigasi ondansetron baru-baru ini menyebabkan peringatan FDA baru mengenai penggunaannya pada pasien dengan interval QT berkepanjangan. Antagonis 5-HT3 lainnya termasuk granisetron, Tropanetron, ramosetron, dan palonosetron. ${ }^{12}$

Ramosetron hanya dilisensikan di Jepang dan beberapa negara Asia lainnya, dan sebagian besar penelitian tentang obat ini sampai saat ini telah terkonsentrasi pada populasi Asia. Sebuah meta-analisis sebelumnya menunjukkan bahwa ramosetron memiliki efek pencegahan terhadap
PONV yang parah. Namun, sebagian besar penelitian tentang ramosetron dilakukan oleh Fujii, dan dikecam keras karena pembuatan data. Mihara dkk. mengesampingkan penelitian Fujii dan melakukan meta-analisis dari RCT yang tersisa pada tahun $2013(\mathrm{n}=1.372)$, dan menunjukkan bahwa ramosetron memiliki efek yang signifikan untuk mencegah PONV dibandingkan dengan plasebo, tetapi efektivitasnya kurang dari yang telah diberikan dalam analisis sebelumnya. Mereka juga melaporkan bahwa ramosetron secara signifikan mencegah muntah awal dan akhir pasca operasi dibandingkan dengan ondansetron, tetapi signifikansi klinis dipertanyakan karena jumlah yang diperlukan untuk mengobati adalah besar. $^{14}$

Palonosetron mewakili perkembangan yang menarik pada kelompok antagonis reseptor 5-HT3. Palonosetron memiliki mekanisme yang unik, berbeda dari agen yang dikembangkan sebelumnya di kelas ini, dan memiliki efek yang lebih kuat dan terus-menerus. Obat ini memiliki karakteristik farmakodinamik unik 
Tabel 2. Dosis Berbagai Antiemetik Dihubungkan dengan Efek Samping ${ }^{11}$

\begin{tabular}{|c|c|c|}
\hline Obat & Dosis & Efek Samping \\
\hline Antagonis Kolinergik & & $\begin{array}{l}\text { Mulut kering, mengantuk, } \\
\text { gangguan akomodasi mata }\end{array}$ \\
\hline Skopolamin & Transdermal patch & \\
\hline Antagonis histamin & & Sedasi, mulut kering, konstipasi \\
\hline Dimenhidrat & $1-2 \mathrm{mg} / \mathrm{kg}$ IV & \\
\hline Prometazin & $12.5-25 \mathrm{mg} \mathrm{IV}$ & \\
\hline Antagonis serotonin & & $\begin{array}{l}\text { Sakit kepala, pemanjangan } \\
\text { interval EKG asimptomatik }\end{array}$ \\
\hline Ondansetron & 4-8 mg IV & \\
\hline Dolasetron & $12.5 \mathrm{mg} \mathrm{IV}$ & \\
\hline Granisetron & $0.35-1 \mathrm{mg} \mathrm{IV}$ & \\
\hline Ramosetron & $0.3 \mathrm{mg}$ IV & \\
\hline Tropisetron & $2 \mathrm{mg}$ IV & \\
\hline Palonosetron & $0.075 \mathrm{mg}$ IV & \\
\hline Dopamin antagonis & & $\begin{array}{l}\text { Sedasi, gelisah, gejala } \\
\text { ekstrapiramidal }\end{array}$ \\
\hline Metoklopramid & $10 \mathrm{mg}$ IV & \\
\hline Droperidol & $0.26-0.625 \mathrm{mg} \mathrm{IV}$ & \\
\hline Fenotiazin & & Sedasi, letargi, kulit sensitif \\
\hline Klorpromazin & $10 \mathrm{mg} \mathrm{IV}$ & \\
\hline NK1 antagonis & & Konstipasi, pruritus \\
\hline Aprepitant & $40 \mathrm{mg}$ PO & \\
\hline Kortikosteroid & & $\begin{array}{l}\text { Gangguan saluran cerna, } \\
\text { insomnia }\end{array}$ \\
\hline Deksametason & 4-5 mg IV & \\
\hline
\end{tabular}

memprovokasi perubahan konformasi reseptor 5-HT3 melalui pengikatan alosterik yang jelas dapat dibedakan dari antagonis 5-HT3 standar. Obat ini juga memiliki waktu paruh yang lebih lama 40 jam, dibandingkan dengan obat yang ada di kelas ini. Karena paruh waktu yang panjang, palonosetron diharapkan dapat mengurangi OINV jangka panjang setelah operasi pada pasien yang menggunakan PCA. Memang, satu penelitian telah menunjukkan hasil seperti itu dengan obat ini. ${ }^{8}$

\section{Antagonis Dopamin}

Reseptor dopamin terdiri dari reseptor D1 dan D2, dan keduanya telah terbukti berperan dalam menyebabkan mual dan muntah.
Metoklopramid adalah antagonis kuat reseptor D2, dan juga bekerja dengan menghambat reseptor $\mathrm{H} 1$ dan 5-HT3. Obat ini juga menghambat reseptor D2 di traktus gastrointestinal, dan meningkatkan reseptor 5-HT4 yang bekerja memperbaiki efek prokinetik dariusus, sehinggamengurangimuntah. Metoklopramid meningkatkan motilitas pada bagian atas dari traktus gastrointestinal, sehingga dapat mempercepat pengosongan lambung, tanpa mempengaruhi sekresi dari gaster, bilier, maupun pankreas. Peristaltis duodenum juga ikut meningkat, sehingga mempercepat waktu transit. Obat ini meningkatkan tonus sfingter gastroesofagus dan menurunkan tonus sfingter pilori, sehingga mampu mencegah perlambatan pengosongan lambung yang berkaitan dengan pemberian opioid. Dosis $10 \mathrm{mg}$ metoklopramid 
Tabel 3. Komplikasi yang Dilaporkan akibat $P O N V^{8}$

\begin{tabular}{l}
\hline Nyeri tenggorokan berat \\
Ruptur esofagus \\
Sindroma Mallory-Weiss \\
Emfisema Subkutan \\
Ruptur jahitan abdomen \\
Perdarahan intraokular \\
Alkalosis metabolik \\
Hiponatremia \\
Hipovolemia (terutama pada anak) \\
Obstruksi jalan napas \\
Aspirasi
\end{tabular}

biasanya yang umum diberikan, dan penelitian meta-analisis terbaru menunjukkan tidak adanya efek samping seperti gejala ekstra piramidal, pusing, sakit kepala, dan sedasi, namun dosis ini tidak terlalu kuat. Dosis $20 \mathrm{mg}$ atau lebih besar, baru memiliki efek antiemetik yang memuaskan. Angka terjadinya gejala ekstrapiramidal dan diskinesia pada dosis 10,25 , dan $50 \mathrm{mg}$ adalah $0,3 \%, 0,5 \%$ dan $0,6 \% .^{12}$

Droperidol adalah antagonis selektif reseptor D2, yang secara kuat berikatan dengan reseptor D2 yang terletak pada area postrema. Obat ini telah terbukti efektif mencegah PONV, dan sama efektifnya jika dibandingkan dengan ondansetron, ataupun deksametason. Penelitian meta-analisis baru-baru ini menunjukan tidak ada perbedaan bermakna antara dosis 0,25, 0,625, 1 dan 1,25 mg. Efek samping yang sering terjadi adalah memanjangnya segmen QT pada EKG, dan terjadinya aritmia ventrikel. Jadi sebelum memberikan obat ini, harus diperhatikan apakah pasiennya memiliki riwayat pemanjangan QT atau tidak.

Fenotiazin bekerja dengan cara menghambat reseptor D2 di CTZ. Selain itu obat ini juga memiliki kemampuan menghambat histamin. Obat ini jarang digunakan, karena waktu paruh yang singkat, dan memberikan efek sedasi yang berat. Antagonis NK1, reseptor NK1 merupakan golongan obat baru, obat ini bekerja terutama pada nukleus traktus solitarius, dan kemungkinan juga pada formasio retikularis, dimana obat ini berikatan dengan kuat pada reseptor NK1 yang berperanan pada refleks muntah. Antagonis NK1 diketahui lebih efektif mencegah muntah daripada mual.

Apreptirant adalah NK1 reseptor antagonis yang secara luas sudah digunakan. Obat ini biasanya diberikan dosis tunggal oral, 1-2 jam menjelang pembedahan. Penelitian pada obat ini menunjukan bahwa obat ini lebih menurunkan gejala muntah pasca operasi bila dibandingkan dengan ondansetron, namun tetap tidak mengurangi rasa mual. $^{8}$

Deksametason, karena mekanisme yang mendasari patogenesis PONV itu kompleks, maka 2 atau lebih obat yang berbeda mekanisme kerjanya sebaiknya diberikan, kombinasi yang sering diberikan adalah deksametason dengan antagonis respetor 5-HT3. Pada beberapa kasus, deksametason paling baik diberikan pada awal pembedahan, karena onset nya yang lambat. Teori-teori sekarang ini membahas mengenai efek antiinflamasi, terutama untuk mengurangi edema dan inflamasi. Deksametason bekerja menghambat sintesis prostaglandin, yang akan mensentisisasi saraf yang berhubungan ke pusat muntah. Obat ini juga mempunyai efek sentral langsung pada reseptor 5-HT3 pada nukleus traktus solitarius. Penelitian yang membandingkan dosis deksametason 4-5 mg dan 8-10 mg sama-sama menunjukan efektivitas dalam menekan muntah, namun tidak ada perbedaan bermakna antara dosis 4-5 mg dengan dosis 8-10 mg. Dosis 4-5 mg berdasarkan penelitian efektif untuk menekan muntah. ${ }^{8,10}$ Tabel 1. Rekomendasi Jenis, Dosis, dan Waktu Pemberian dari Berbagai Antiemetik1.

\section{PONV pada Pasien Pasca Operasi Bedah Saraf}

Operasi bedah saraf umumnya dilakukan dengan menggunakan anestesia umum. Jenis-jenis operasi bedah saraf antara lain operasi evakuasi perdarahan otak, operasi tumor otak, operasi tulang belakang, operasi kelainan vaskular otak (aneurisma, malformasi arteri vena) dan operasi lainnya. Operasi bedah saraf dilakukan dengan 
berbagai macam posisi, misal posisi supine, prone, lateral, park-bench. Pada operasi tumor otak, PONV mungkin tidak hanya berdampak negatif pada kenyamanan dan kepuasan subyektif pasien, tetapi mungkin juga memiliki implikasi ekonomi yang besar, karena menyebabkan keterlambatan pasien untuk keluar dari rumah sakit, dan untuk dapat segera melakukan rawat jalan. Selain itu, PONV juga dapat menyebabkan komplikasi serius, jarang terjadi, tetapi mungkin memiliki minat khusus pada kelompok pasien yang berbeda. Tabel 3 memberikan gambaran dari mereka yang telah dilaporkan sebagai konsekuensi dari muntah dan muntah, sebagian besar telah dilaporkan dalam laporan kasus atau serial kasus kecil. Meskipun kasus perdarahan intrakranial yang terdokumentasi karena mual atau muntah pasca operasi tidak banyak, adalah wajar untuk menganggap bahwa ini adalah ancaman yang serius. Stimulasi simpatis pada fase pra-ejeksi dari refleks muntah, dan hipertensi arteri terkait yang dapat secara teratur terlihat pada pasien dengan pemantauan tekanan darah arteri invasif saat sedang mual, dapat mempersulit upaya untuk menjaga tekanan arteri rata-rata dalam rentang stabil pasca operasi. Bahkan, peningkatan tekanan intraabdominal dan intratoraks selama fase ejeksi, secara langsung menyebabkan tekanan intrakranial yang tinggi. Selama muntah-muntah aktif dan muntah, tekanan intraabdominal dapat meningkat hingga lebih dari $100 \mathrm{mmHg} .{ }^{17}$

Gejala retching yang terjadi dianggap sebagai upaya untuk mengatasi penghambat anti-

Tabel 5. Dosis Berbagai Antiemetik dihubungkan dengan Efek Samping

\begin{tabular}{llllllll}
\hline $\begin{array}{l}\text { Jumlah } \\
\text { Faktor } \\
\text { Risiko }\end{array}$ & Apfel & $\begin{array}{l}\text { Jumlah } \\
\text { Faktor } \\
\text { Risiko }\end{array}$ & \multicolumn{3}{l}{$\begin{array}{l}\text { Koivuranta et al } \\
1997\end{array}$} \\
\hline 0 & 1 & 0 & $\%$ & 0 & 1 & 8 & $\%$ \\
1 & 2 & 0 & $\%$ & 1 & 2 & 0 & $\%$ \\
2 & 4 & 0 & $\%$ & 2 & 4 & 0 & $\%$ \\
3 & 6 & 0 & $\%$ & 3 & 5 & 5 & $\%$ \\
4 & 8 & 0 & $\%$ & 4 & 7 & 5 & $\%$ \\
& & & 5 & 9 & 0 & $\%$ \\
\hline
\end{tabular}

Dikutip dari Moon, Young Eun. Postoperative Nausea and Vomiting. Korean Journal Anesthesiology, 2014: 164-70
Tabel 4. Faktor Risiko PONV

\begin{tabular}{ll}
\hline Apfel et al 1998 & Koivuranta et al 1997 \\
\hline Jenis kelamin wanita & Jenis kelamin wanita \\
Riwayat PONV & Riwayat PONV \\
Bukan merokok & Motion sickness \\
Pemberian opioid & Bukan perokok \\
pascaoperasi & \\
& Durasi pembedahan $>60$ \\
& menit \\
\hline
\end{tabular}

Dikutip dari Eberhart L.H.J, Morin A.M, Kranke P. Prevention and control of postoperative nausea and vomiting in post-craniotomy patients. Best Practice \& Research Clinical Anaesthesiology. 2007; Vol. 21 No. 4: 575-593

refluks yang ada di wilayah persimpangan gastroesofagus. Baik mual dan muntah, terutama melibatkan kontraksi otot-otot somatik pada dinding abdomen dan diafragma. Selama proses retching, otot perut dan seluruh diafragma berkontraksi serentak, sedangkan selama proses muntah diafragma periesofagus akan menjadi rileks, hal ini terjadi mungkin untuk memfasilitasi keluarnya isi lambung melalui kerongkongan dan ke luar. Dengan demikian, proses keluarnya isi lambung disebabkan oleh kompresi lambung oleh diafragma dan kontraksi otot perut bagian bawah yang diakibatkan pengaruh saraf motorik somatik. ${ }^{17}$

\section{Bukti adanya Peningkatan atau Penurunan Risiko untuk PONV pada Pasien Pasca Kraniotomi}

Pertanyaan ini sulit dijawab karena PONV tidak diragukan lagi merupakan masalah multifaktorial. ${ }^{5}$ Dengan demikian, hasil dari uji klinis yang berbeda pada kejadian mual dan muntah tidak dapat dibandingkan secara langsung. Hanya beberapa penelitian yang melaporkan lengkap mengenai risiko individu pada pasien yang direkrut dalam uji coba. Pada penelitian-penelitian sebelumnya hampir semua penelitian melaporkan distribusi PONV antara laki-laki dan perempuan, atau menurut usia pasien, namun masih terdapat banyak kekurangan informasi tentang faktor risiko lainnya, seperti status merokok atau PONV sebelumnya. Namun semua informasi seperti itu, diperlukan untuk 
memperkirakan kejadian yang diharapkan dari PONV untuk memungkinkan perbandingan antara studi. ${ }^{5,6}$

Dalam penilaian ulang baru-baru ini, kumpulan data epidemiologi yang besar dapat ditampilkan bahwa, di antara faktor-faktor risiko lainnya, lokasi operasi hanya memiliki nilai prediktif yang minimal mengenai terjadinya PONV. ${ }^{10}$ Variabilitas dalam jenis anestesi yang dilakukan dan masalah metodologis dengan tindak lanjut pasca operasi lebih lanjut membatasi komparabilitas uji klinis yang berbeda, meskipun ada berbagai rekomendasi tentang bagaimana studi tentang PONV harus dilakukan. ${ }^{8-10}$

Penelitian-penelitian prospektif pada kejadian PONV, dilakukan dengan memberikan pertanyaan berulang kali mengenai keluhan muntah, dan akibatnya akan menghasilkan insiden mual/ muntah yang jauh lebih tinggi dibandingkan pada percobaan yang dilakukan retrospektif dengan menggunakan skala PONV 1 sampai 10 atau adanya administrasi dari suatu obat antiemetik, untuk mendefinisikan pasien menderita PONV. Hal lain yang juga penting, beberapa pasien mungkin salah menginterpretasikan keluhan sakit perut atau perasaan umum sakit atau mual, terutama saat keluhannya sedang berlangsung. Setelah meninjau beberapa penelitian yang mempelajari kejadian mual dan muntah setelah tindakan kraniotomi, didapatkan hasil bahwa belum ada data yang jelas mengenai PONV pasca kraniotomi, apakah risiko nya lebih tinggi ataukah lebih rendah. Perbedaan yang terlihat pada pasien dengan supratentorial versus prosedur infratentorial dapat dijelaskan oleh durasi operasi. Ada bukti yang baik bahwa jumlah obat yang diberikan untuk anestesi (maksimum durasi konsentrasi yang dapat diterima) berkorelasi dengan kejadian PONV, terutama dengan penggunaan anestesi inhalasi dan selama jam-jam pertama setelah pembedahan. ${ }^{11}$ Kemudian, opioid pasca operasi diberikan untuk menghilangkan rasa sakit dianggap bertanggung jawab untuk sebagian besar episode dari PONV. Dengan demikian, adanya perbedaan nyeri pasca operasi yang terlihat pada berbagai jenis operasi mungkin merupakan alasan utama untuk terjadinya tingkat keparahan PONV, terutama pada periode akhir pasca operasi. Tempat prosedur bedah saraf pada penelitian juga mungkin kurang berpengaruh sehubungan dengan PONV, dan dianggap sesuai dengan derajat nyeri pasca operasi. Satu penelitian secara retrospektif membandingkan kejadian PONV setelah operasi dengan metode awake craniotomy dibandingkan dengan prosedur yang dilakukan di bawah anestesia umum. ${ }^{17}$ Dalam 4 jam pertama setelah operasi, kejadian mual secara signifikan lebih rendah (4\%) dan muntah $(0 \%)$ pada pasien dengan awake craniotomy daripada pasien yang mengalami anestesi umum (23\% mual dan $11 \%$ muntah). Namun setelah 4 jam, ketika opioid pasca operasi telah diberikan kepada sebagian besar pasien dari kedua kelompok, kejadian mual dan muntah menjadi sebanding. ${ }^{12}$ Hasil ini mendukung pemahaman kita yaitu anestesia umum adalah faktor risiko yang sangat penting untuk PONV, dan ini juga berlaku untuk pasien kraniotomi. Selanjutnya, survei mempelajari faktor risiko yang terkait dengan PONV pada pasien pasca-kraniotomi juga menunjukkan bahwa jenis kelamin pasien adalah yang paling banyak faktor penting bahkan dalam pengaturan kraniotomi. ${ }^{11,17}$

\section{Peranan Skoring Faktor Risiko pada Pasien Pasca Kraniotomi}

Pencarian faktor risiko untuk memprediksi terjadinya PONV pada masing-masing pasien dimulai oleh publikasi Palazzo dan Evans pada tahun 1993, di mana skoring faktor risiko pertama berasal dari total 147 pasien. Pada pasien-pasien ini, banyak potensi faktor risiko yang dicatat dan dianalisis secara retrospektif untuk memberikan nilaimerekauntuk diprediksiPONVmenggunakan analisis regresi logistik. Pada tahun-tahun berikutnya, beberapa penulis memiliki mencoba mengoptimalkan pendekatan ini. ${ }^{5,14}$ Upaya-upaya telah mengarah pada berbagai skoring faktor risiko yang berbeda, termasuk metode yang sangat canggih dengan jaringan saraf tiruan..$^{15,16}$ Sayangnya, semua model prediktif menghasilkan hasil yang cukup mengecewakan saat dinilai pada pasien. ${ }^{6,17}$ Namun, dua dari mereka telah muncul sebagai beberapa relevansi klinis, menggunakan model disederhanakan. Keduanya disederhanakan 
skor memungkinkan estimasi sederhana dari risiko seorang pasien individu untuk menderita PONV: mereka menghitung jumlah faktor risiko yang relevan dari daftar yang telah ditetapkan. Jumlah seluruhnya sejumlah faktor digunakan, dan angka ini dapat dikonversi menjadi kemungkinan yang diberikan untuk mengembangkan PONV dalam satu pasien. ${ }^{5,14}$ Faktor risiko yang relevan dari dua disederhanakan skor tercantum dalam Tabel 2, dan risiko yang diharapkan dari PONV untuk kehadiran 0-4 / 5 faktor risiko digambarkan pada Tabel 3.

Kedua skoring di atas telah berulang kali divalidasi dalam survei prospektif dan studi klinis dalam tindakan bedah yang berbeda, dan sebagian besar hasil mengkonfirmasi bahwa kedua skoring tersebut cocok untuk memprediksi kejadian PONV pada sekelompok pasien. Di satu sisi, ini menyoroti fakta bahwa jenis operasi hanya memiliki dampak terbatas pada terjadinya PONV di sisi lain, setelah lebih dekat melihat diskriminasi kekuatan skor, menjadi jelas bahwa mereka memiliki nilai terbatas untuk suatu pasien individu. Kekuatan diskriminatif adalah kemampuan skor risiko untuk benar mengidentifikasi pasien itu dari dua orang yang menderita PONV sementara yang lain tidak. Penerapan skor PONV dapat meningkatkan peluang untuk benar membedakan dari 50\% (tebakan acak) hingga $72 \%,{ }^{6,18}$

Keputusan kapan dan kapan tidak mengelola antiemetik sangat tergantung pada tujuan individu, misalnya, yang diinginkan mengakibatkan timbulnya PONV atau pertimbangan efisiensi biaya yang diterapkan antiemetik. Jika misalnya, kejadian perkembangan PONV dianggap membahayakan pasien, maka tidak diperlukan penilaian risiko pra operasi, dan antiemetik multimodal rutin profilaksis harus diberikan. Jika risiko akibat muntah dan muntah dapat dikesampingkan, skor saat ini dapat digunakan untuk menerapkan kebijakan anti-PONV lokal standar. Dengan menggunakan kebijakan ini, dapat beralasan untuk melakukan penggunaan profilaksis PONV kombinasi (misalnya deksametason plus 5-HT3-antagonis) pada pasien dengan peningkatan risiko PONV.

\section{Implikasi Klinis}

Sebaiknya keputusan untuk memberikan antiemetik pada pasien pasca operasi bedah saraf diberikan melalui pertimbangan patient-oriented. Hal ini penting untuk dilakukan terutama pada pasien yang bila mengalami gejala mual atau muntah akan mengakibatkan komplikasi yang serius. Pada pasien pasca operasi bedah saraf, keputusan untuk memberikan antiemetik tidak hanya berdasarkan kalkulasi faktor risiko mual-muntah saja, namun juga berdasarkan pertimbangan bahwa pasien akan mengalami pengaruh tidak baik pada kualitas hidupnya. Pada kasus tersebut, pemberian antiemetik multimodal perlu dipertimbangkan untuk mengurangi insidens PONV. Bukti penelitian menunjukan bahwa terapi PONV pada jenis operasi lain, bisa bermanfaat bila diberikan pada pasien pasca kraniotomi. ${ }^{17}$

\section{Rekomendasi Klinis}

Jika obat antiemetik akan diberikan kepada pasien sesuai indikasinya, maka pemberian kortikosteroid pada awal operasi dibantu dengan obat golongan 5-HT3 antagonis atau antagonis reseptor D2 pada akhir operasi, membantu memperkuat efek anti mual dan muntah. Obatobat golongan tersebut diketahui tidak memiliki efek samping klinis yang signifikan, dan juga tidak mempengaruhi status kardiovaskular pasien pada pasien normovolemia. Bila terjadi hiperglikemia pasca pemberian kortikosteroid, sebaiknya diberikan terapinya. Terapi dengan antihistamin seperti dimenhidrat, dikatakan juga mampu membantu mengatasi PONV pada operasi bedah saraf, namun ada efek sedasinya yang tentu harus diperhatikan ketika memberikan obat golongan ini. Nitrous oxide, gas anestesi yang mempunyai efek emetogenik, sebaiknya juga dihindarkan pada kasus operasi bedah saraf, disamping juga berpengaruh terhadap aliran darah otak dan vasodilatasi serebral. Penggunaan anestesi intravena seperti propofol, merupakan faktor penting juga dalam pencegahan dan penganan PONV multi modal. ${ }^{17}$

Penelitian yang dilakukan oleh Audibert tahun 2004, Setelah operasi bedah saraf, persentase 
pasien dengan mual sekitar 50\%, sedangkan yang muntah sekitar 39\%. Hasil ini mirip dengan penelitian yang dilakukan oleh Latz tahun 2011, persentase pasien dengan mual yaitu $47 \%$ dan yang mengalami muntah sekitar 33\%. Faktor risiko PONV pascaoperasi bedah saraf adalah jenis kelamin wanita, operasi daerah infratentorial, dan anak usia diatas 2 tahun memiliki risiko yang lebih tinggi. Latz sendiri mengatakan bahwa operasi bedah saraf itu sendiri seharusnya menjadi prediktor PONV juga. Hellickson 2016, menyatakan faktor risiko PONV pada 24 jam pertama pasca operasi adalah wanita usia muda, dan riwayat mengalami PONV sebelumnya, sedangkan setelah 24 jam, faktor risiko PONV yang signifikan hanyalah wanita usia muda. Untuk mengurangi risiko tersebut, disarankan untuk menggunakan propofol saat induksi dan pemeliharaan anestesia, menghindari penggunaan $\mathrm{N}_{2} \mathrm{O}$, dan hidrasi yang cukup sebelum induksi. Pada anak droperdol tidak direkomendasikan, dan metoklopramid tampaknya tidak memiliki efek yang memuaskan. ${ }^{18-20}$

Patofisiologi dari wanita post-pubertal yang memiliki risiko tinggi mengalami PONV masih belum dapat dijelaskan, dugaan yang berkembang adalah terkait dengan adanya fenomena hormonhormon wanita yang berbeda dengan wanita usia tua. Namun belum ada bukti kuat menunjukan adanya hubungan antara siklus mensttruasi dengan timbulnya PONV. Wanita usia tua dihubungkan juga dengan berkurangnya refleks autonom yang menyebabkan mual dan muntah. ${ }^{20}$ Dari penelitian yang dilakukan, faktor-faktor yang berhubungan dengan pembedahan, termasuk lokasi operasi, lama operasi menunjukan hasil yang tidak konsisten. Operasi infratentorial dihubungkan dengan lebih tingginya angka PONV, dihubungkan dengan kerusakan dari CTZ yang mungkin terjadi selama pembedahan, selain itu juga durasi operasi yang lebih lama turut berpengaruh pada persentase PONV yang lebih tinggi. ${ }^{20}$

\section{Simpulan}

Postoperative nausea and vomiting merupakan suatu komplikasi operasi yang sering terjadi, walaupun tidak menyebabkan mortalitas, namun dapat berpengaruh pada morbiditas pasien terutama pasca operasi bedah saraf, yang mana pada kondisi pascaoperasi kejadian mual atau muntah dapat berpengaruh pada peningkatan tekanan intrakranial, dan risiko terjadinya perdarahan ulang pada area bekas operasi. Faktor lokasi tumor apakah supratentorial atau infratentorial mempengaruhi insidens PONV. Pada kasus tumor infratentorial insidens PONV lebih banyak, karena dihubungkan dengan durasi operasi yang lebih lama, sehingga obatobatan yang digunakan juga lebih banyak, juga pengaruh dari lokasi infratentorial itu berdekatan dengan area pusat muntah, seperti ventrikel 4, medula oblongata. Tatalaksana PONV pada kasus operasi bedah saraf sama seperti operasi jenis lainnya, namun juga perlu dipertimbangkan faktor individual yang mempengaruhi, tidak hanya berdasarakan pada skoring faktor risiko yang sudah baku.

\section{Daftar Pustaka}

1. Gan TJ. Consensus guidelines for The management of postoperative nausea and vomiting. Anesth Analg, 2014: 85-113.

2. Koivuranta $M$, Läärä E, Snåre L, Alahuhta S. A survey of postoperative nausea and vomiting. Anaesthesia, 1997 May;52(5):4439.

3. Fortier J, Chung $\mathrm{F}$, Su J. Unanticipated admission after ambulatory surgery a prospective study. Can J Anaesth 1998 Jul; 45:612-9.

4. Gold BS, Kitz DS, Lecky JH, Neuhaus JM. Unanticipated admission to the hospital following ambulatory surgery. JAMA 1989 Dec 1;262(21):3008-10.

5. Tramèr MR. Strategies for postoperative nausea and vomiting. Best Pract Res Clin Anaesthesiol 2004; 18:693-701.

6. Mehernoor WF. "Postoperative nausea and vomiting Its etiology, treatment and 
prevention." Anesthesiology, 1992: 162-84.

7. Larsson S, Lundberg. "A prospective survey of postoperative nausea and Vomiting with special regards in incidence and relations to patient characteristics, anesthetic routines and surgical procedures." Acta Anaesthesiol Scand, 1995: 539-45.

8. Moon YE. "Postoperative Nausea and Vomiting." Korean Journal Anesthesiology, 2014: 164-70.

9. Rueffert H, Thieme V, Wallenborn J, Lemnitz N, Bergmann A, Rudlof K, et al. Do variations in the 5-HT3A and 5-HT3B serotonin receptor genes (HTR3A and HTR3B) influence the occurrence of postoperative vomiting? Anesth Analg 2009; 109: 1442-7.

10. Nakagawa M, Kuri M, Kambara N, Tanigami H, Tanaka H, Kishi Y, et al. Dopamine D2 receptor Taq IA polymorphism is associated with postoperative nausea and vomiting. J Anesth 2008; 22: 397-403.

11. Hikasa Y, Ogasawara S, Takase K. Alpha adrenoceptor subtypes involved in the emetic action in dogs. J Pharmacol Exp Ther 1992; 261: 746-54.

12. Apfel CC, Korttila K, Abdalla M, Kerger $\mathrm{H}$, Turan A, Vedder I, et al. A factorial trial of six interventions for the prevention of postoperative nausea and vomiting. N Engl J Med 2004; 350: 2441-51.

13. Carlisle JB, Stevenson CA. Drugs for preventing postoperative nausea and vomiting. Cochrane Database Syst Rev 2006; (3): CD004125.

14. Kim WO, Koo BN, Kim YK, Kil HK. Ramosetron for the prevention of postoperative nausea and vomiting (PONV): a meta-analysis. Korean Journal of Anesthesiology. 2011; 61: 405-12.

15. Henzi I, Walder B, Tramèr MR. Metoclopramide in the prevention of postoperative nausea and vomiting: a quantitative systematic review of randomized, placebo-controlled studies. British Journal of Anaesthesiology 1999; 83:761-71.

16. Wallenborn J, Gelbrich G, Bulst D, Behrends $\mathrm{K}$, Wallenborn $\mathrm{H}$, Rohrbach A, Krause U, Kühnast T, Wiegel M, Olthoff D. Prevention of postoperative nausea and vomiting by metoclopramide combined with dexamethasone: randomised double blind multicentre trial. BMJ 2006;333:324.

17. Eberhart LHJ, Morin AM, Kranke P. Prevention and control of postoperative nausea and vomiting in post-craniotomy patients. Best Practice \& Research Clinical Anaesthesiology. 2007; (21)4: 575-93.

18. Audibert G, Vial V. Postoperative nausea and vomiting after neurosurgery (infratentorial dan supratentorial). Annales Françaises d'Anesthésie et de Réanimation 23. 2004; 422-7.

19. Latz B, Mordhorst C, Kerz T, Schmidt A, Schneider A, Wisser G, et al. Postoperative nausea and vomiting in patients after craniotomy: incidence and risk factors. Journal of Neurosurgical Anesthesiology. 2011;114: 491-6.

20. Hellickson JD, Worden WR, Ryan C, Miers AG, Benike DA, Frank SP, et al. Predictors of postoperative nausea and vomiting in neurosurgical patients. Journal of Neuroscience Nursing. 2016; (6):352-7. 